\title{
Trust and Civic Participation in Korea
}

\author{
SOOK-JONG LEE \\ The lejong lnitituite
}

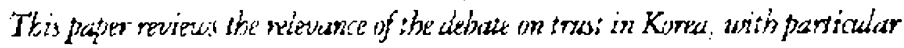
fous on the ditionen: levels of truit. While fanilial and interpersonal irust

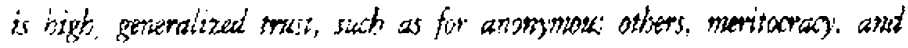

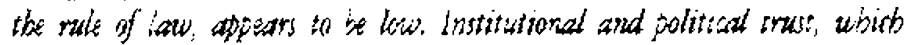
is a spectfor form of generaitzed trass, is esperzally lou Younger, beiler ecturated,

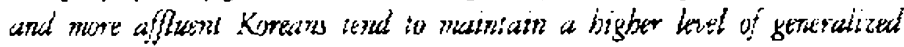

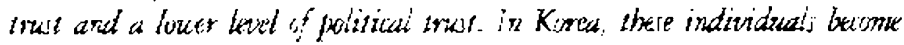

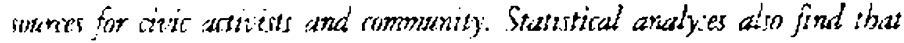

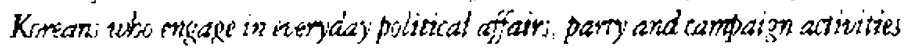

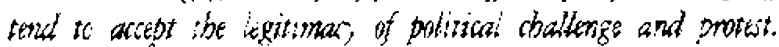

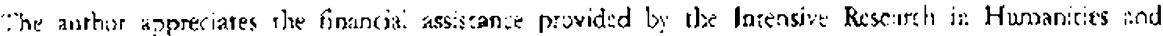
Fxia. Sernences (15;)y) from. Kerea Kesearch Fourdation.

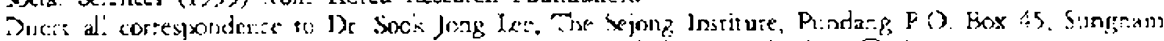

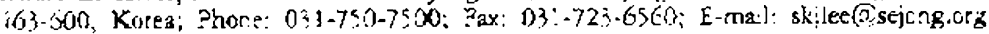




\section{INTRODLCTION}

7 he study of "truse" has become someting of a growth industry with the rise: 1 of the recenr debate or. "social rapiral," anci irs implicat:ons for politics and conomics While being a component of soria' rapital, roust is essential.y an individua"s stare of rind toward other people or :ostitutions

At the interperso:al evel, as Hardir. (1998) argued, trust is a form of "encapsulated ircerest": A rmasts $B$ becalise A presumes that it is in 3 's interes: to act in a ray

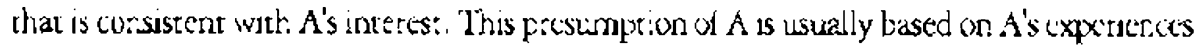
with B. In tise tatenal docice approach, roany studes have emphasized the node of

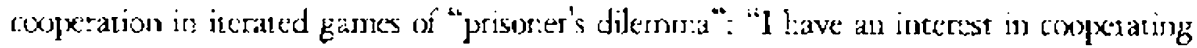

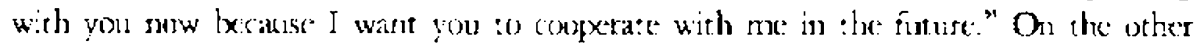
hand, genesalized taus: in society implics a lagge numioer of ancnymous persoral irceracticns. Institntional trus: is a sixritir torn. of generaized trust, which applies to mijor institutions in a given society. Whea cne assesses the fairness of sorial arrangements or the tuustworhiness of $F$ 'abic aitho:ity, the criteria is certain'y different from tha: of the prisoner's dilemma. 'These two !eve's o. mist, i.e., interpesonal and institutional, are reiated to tach ethe: in complcared but ilearly interactive ways.

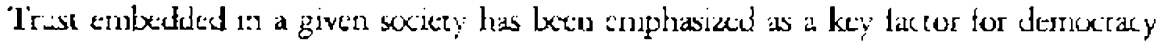

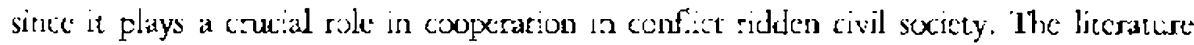

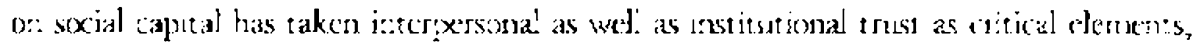
although few studies address this reiaticuship. Raising the question of trust in the Korean sociery is of particular interest as discussions on Korcan democrany have often included the thesis that consclidaied demoracy has been delayed in Korea due to lack of trust.

This paper examiries the current state of thist, the patterss of people's engazement in civic associations, anc their attirudes tcward political pazicipaticn in Korta. Due to unavailabi'ity of integrated survey data, this paper reviews these issues using a sejarate, descriptive incthixd.

\section{REI.EVANCF OF THE TRISST DEBATE TO KORFAN SOCIETY}

\section{Rise of Large Ciric Associations as Social Capital}

Coleman (:988, 98), who inve'zte: the term "social capital," defines it by its functions. Fe nutes that "like other ferms of cap:al, soc:al capital is productive, making passisle the achievement of certain ends thai in ins absernce would not kx possible." Tiss concepr of suxial adpital as as sexial resounce for "geteng things done" was further claborated

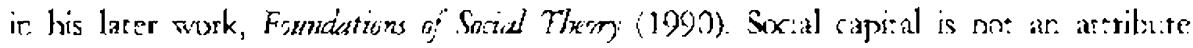
of indivicuals, but rather "inheres in the structure of relations herwecen pxisons and amor.s persons" (Coleman 1990, 302). Coleman identities :ypes of social capital as "obligations and expectations" among individuals, "in Ermation potentia!," "norms and 


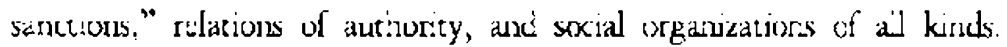

As Foley and Edwards (1997, 552) rightiy poin: out, soxial capital for Coleman exists varying scales of sorial relarions of all sorts. It exists on.y insofar :L these relaricrus provide resources for some acrion; is is no: a metaphysical charactemistio of sociery, nor is is explicitly tiec to the functioning o: dernocracies. This rather ne.utral concent et social capital is distinguishable from the use of socia casital by zec-Tocquevillians, who tend to view social capital as a sivic value that fosters civic engage:nent and, ultimately. democrary.

Putnam popularized the corcept of sck:al capial in this fastion. He defines suxial capital as "features of scxial organization suill as networks, nornos, and socia trist thar

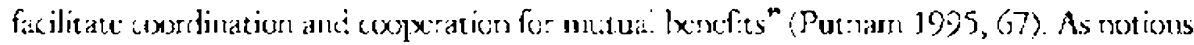

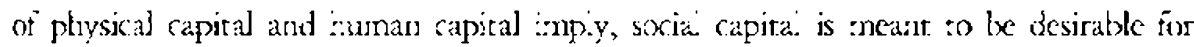
democratic politios and eccnomic nerfesmance

Fot Pa:nam, rot every network of civic eagagerzent can generate socia capitai. Suxial connectedness and socia. trust are createc frcm secordacy associations when face-toface inte:actions are possib.a. 'Desp:te groning nex rass-membership, nonprofi: organizations anc sei-heip support groups. Plinan sees a decline of social capial in civic America as membership in regular churcigoers, lasor unions, parent-teacher asso-

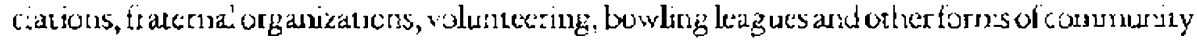
organizatous has shrunis.

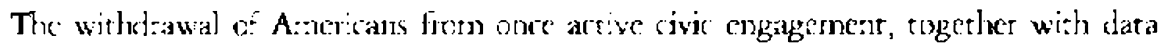
stow: ng a risc in public dist:usr is understonc by many nen-Toquevilitians to be responsible for the dedine in political participation. exidenced by decining voting races, sixich: are problematic tor a healthy smerican cemocracy. However, decliaing civic ergagement by contemporary tmericans is less worrsome for other sciolars, ar least at the loxal eve. For example, $5 k x p$ c. points out that luxal community organizations and neighborhoud groups at ill involve people, while reai change is oxcurring at the national level. Sne argues that "the vid civic Antrican has seen bypassed and sheved w the side by a gaggle of professionally dominated atrocasy grocips anc nenprofit

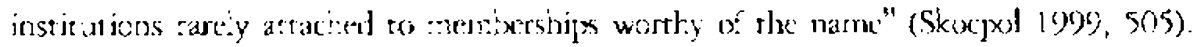
The great ransfornation "rom memberstip to adveary" in civic Amerina dominated by contealized, staff-driven advocacy issociations is seen as erciing bridges betreen c.asses and places, and herween local and ransioca affajrs.?

Punam ard Sisocpol share the value of civic America to be embedded is. local grassroot

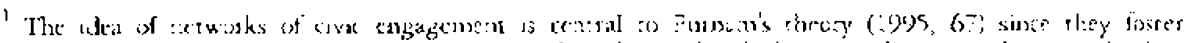

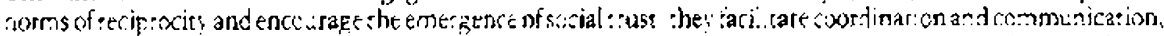

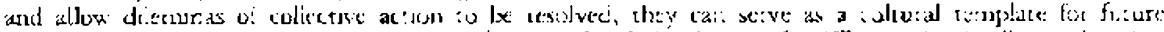

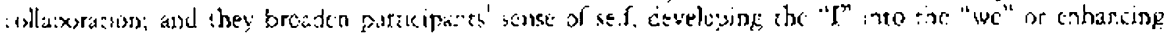

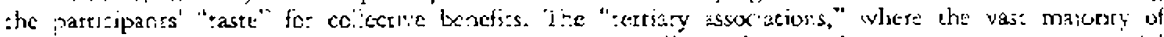

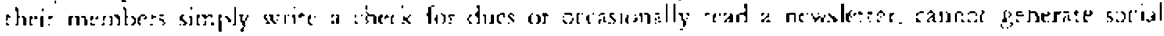
snust.

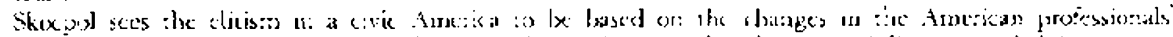

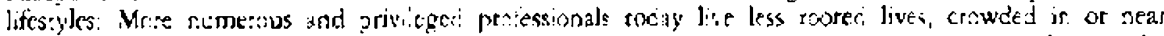

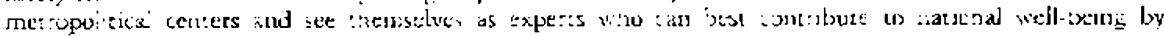
ourixisp, with, orter sitecia.isrs.
} 
civie associations, anci thas their contempt for bureaucratized national ones. Hewever,

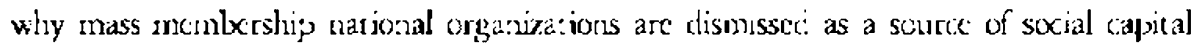
is anclear. Mink off criticizes the downolaying of sorial movemenu organizations dis missed by Purnam as terriary associarions tha: fones on artionaism and hierarchical bureaucracies as unfair. "Metia:ed or atostract eelations thar do not entail face-:o-face interaction. may also provide a tasis for sclidarity anc colective idertity, repressncing an alternative soutce of social capital" (Minkoff 199\%, 6:0).

'Ihis criticism is certainly valid for many countries where commurity-based voluntary associations are organized for the sake of mulud help, and this are rot inked to a rew'y emerging civil socie:y movemert. Korea is certanly a case where the civil

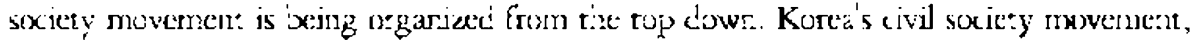
led by major nationwide civic asoxiat:ons, las lxen thataceried by the legacy of andi-authoritanian civil soriety movements and advorary arriviries of civis assoriarions after democrazization. Therefore, in the Korean setting, the rise of large civic assoriations signifies the "capitalization," rather than the "decapitalizaticn" of society.

\section{Familial Yrust and Genteralized 'inust}

'lhe pupular ciebate on exuse in Asian swcie:ies was spasked by Fukliyana's thesis.

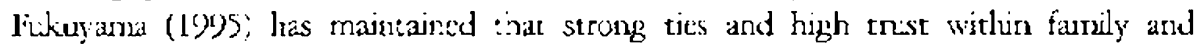
sunall we-group of classmates ot friends do no: diffuse to high trust of larger groups or socicty: as sce ir many Asian secictles. Fukuyama's trist is also functiona' in terms of eccnomir prosperity and demorrary. Soxieties with a smal. radius of :nuse, sirh as China anc Korea, are describec to be less suitahle for mociern inciustrial capizalism. In his lates writing. Fukuyama links his narrow trast argument with poor democratic pefformance. He mantainec tha: the most distincsive Asian values ase at:itucies :oward sorial orders, such as family, gender coles, and kinsmip, rather than folitical order.

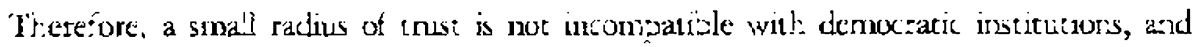
the problems creace by a smal' radius of trust have mere to do with the quality of

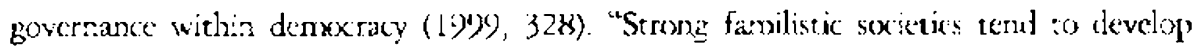
a swo-tier systrm sf ethira' values, kith higher standards of behavior reserves for relations within the tamuly o: other yrxs o: pesonal rearions and lower ones for public life. One conscquence is a rela:vely low level of civic obigarion and hence a greater propensity for political cornupior" (:949, 328-29;. Edward Barfielc's concept of "amoral fami:sr." anxong poor Italicas or the Korean concept of "family egoism" shares Fukuyamás criricism of cow trust socie:ies wirhin which trus! ex:ends orily to insiders.

However, this viewpon: is differer: fom the argun:tni nade by social capital

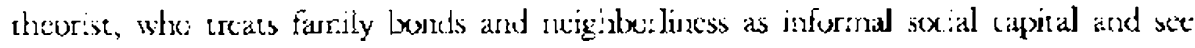

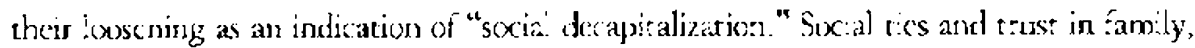
schos., and workplace, where genple spend more rime und are involved wirt more emotional rommitmenr, are recosnized as be sources of sixial capital cother than volunaty associaciors: Colconar. (1988, 10\%-1:6) stresses the importance of the family 


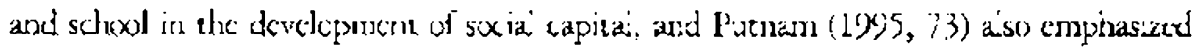
family as the most inportant form of sexial capjal; Verba et al. (1995, 320) claim rhat the wokpace provides the rrost opportunites for the pracries of civie skills. If the high trist of informal groups sucis as kinship retworks is present with the low tust of formal institutions or society, one has to se aurious in interpreting their relationship. Exclusive farnily tous: can cartainly suppress gene:alized reciprocity and cooperation wich other exiemal grouss. Nepotistic, regional and school ties iend to produce a segmented suciety (Let 1998). Bus, h.igh tnus: and cense necworks within

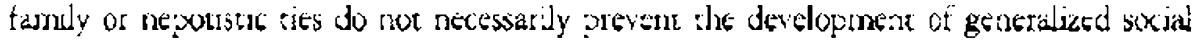

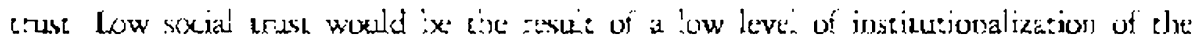

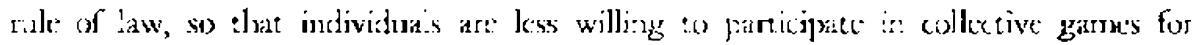
cooperation. As derroxatic ales are institutionalized, therefore, the small radius of inust is likely ro expand into a larger ratilis of rmass.

While this paper so far empotas:zes the institutional context of expansion of family toust to gerera'ized trust. Yamagist: rebuts the kinesis of high interpersona. trust among the Japanese. He argries shat Japanese cust for others is actually loner than that of the America.ss, and he also argies tha: tnist, in Japarese society, is not cultural

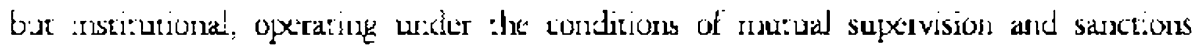
(Yamagishi et al. :9) S). Yamag!shi conctucis that staslc soc:al and organizaticnal

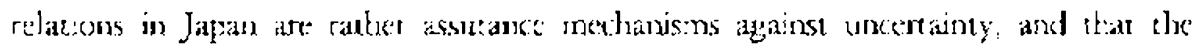
Japresese tend to lingit acir reations 00 exclusive ties dee to the low evel of genctal twuse. In particilar, hizh conmitrent by the Japancese to exclusive social relations and t) the workplace is a result of low trist and high uncertainty (Yamagishi et al. 1998). This theory explains winy aparese economic excrange. as is the keiretsu selationship. tends to $x$ internalized within setrorks and why outsiders must endure high investrent costs to enter the relationship

Kin and Sori 11998; also fand :a their experinkent of "trust as an event" that dxe cflex: of sarctions in increasing cooperation tends to lo grcalct anomg Kureans inan among japancse. The Eat that cooperat:on among Ko keans requires sanctions, they argue, sageests why the eollapse of a sancrioring mechanism leats an great social risk in Koreiz.

The thesis of the viability of instiucricnal inss under the condition of sanctioning mechanisms in Japan and Ko:ea may well be valid. Trust jased ca singevisions and sancions would be fragile and costly. Nevertheess, enujuring a long-terr. assurance mechanism can develop into tnust, although Yamagish: (1998) argues that the very lack cf trust generates assurance in the first jlace. If cooperatyon is maintained with the

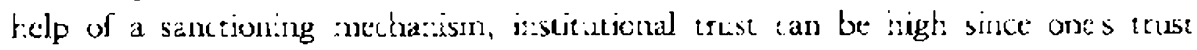

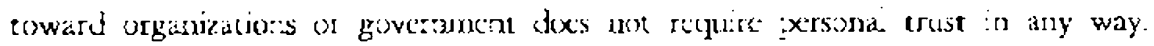

\section{rrast and Goternance}

There is litrle at:ention in recent Lieerature or social capital or toust concerning the 
role of ve statc in influen(irg generabized trus: As levi (19978, 84) points out, "states often redece the nece: for citizers to trast each other, or they may fatilate trust by solving the esses:ial information, monitoring, and enforement problems, or both." She argues, however, that infrastructure and resources are nor sufficient conditions for the state to perfo:m ts tr.ust-produc:ag rolc unless citizens recugnize the credibility and conpetence of the sate (Levi $998,85-86$ ). Citizens are likely to :rust govenment ony to the extent that they beieve that it will act in their interes's, its procedures are fair, and their trust of the state and of cohens is reciprocated.

the thess that the trastwortuncss of the statc intuences its capacity te gencrate miterpersural :rust is very mopurtant to unders:anding the min:ntutional or getneralized trust of recently democratized societies, where the legacy of iastitutional distrist

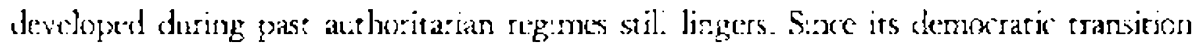
in 1987, Korea has becr: exwerrencing more than a decade.long tria and etror phase to consolidate demoracy. With all the cortiruous poitical reforms, the Korean goverament and politic:ans have nut earred tuus:wo.thiress from the populace. As oppressive sanct:ons were eradicated with polit:cal 'iberalization, volun.rary consent became crticial to the democratic governance of the state. However: contemporary Koreans have become nucreasingly cyncal towards politics as tiey fee. that ongcing reforms have rot

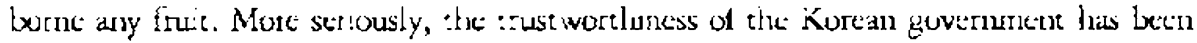
impaired as its poidcies have lexrn subject to the pressurc of inte-esi groups and elderefore

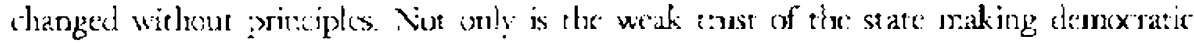
goverstaner diffirult, Sur it alsu hampes the deveiopmert of institutional enust

\section{STATUS OF 'TRUSI' IN KOREA}

This section examines the star.is of trast 1n Korea. Three kinds of irass, i.e., familial, generaized, and institutional and solitica. wi.l be reviewed through several recert survey datia.

\section{Famitial Trust}

Xorean family res remair. strong despite the "nuclearlization" of family stricture during Koreas rapic incustrialization and urbanizaticn. In 1996.79.8\% of Korean farnilies were in a ruclear bamly structure, while or.y $9.1 \%$ of them had extencied families composed of a married couple with their paren:(s) (National Information Office 19x)8, 115). However, residential separator: has not chluted the sigrifneance of fannily in Ko:car: society. Korcan facnily ues iave bxcimk eren sureager with the derline of

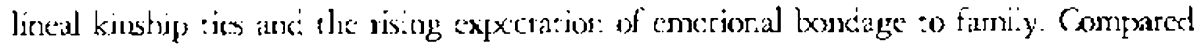

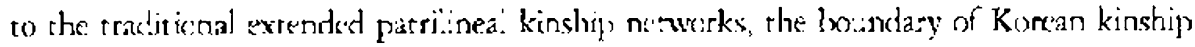
has heen narscwes, often not srarscending heyocd cousins. Instead, today's Korean family mainteins strong ses anc frequent interacticus within she suclear bourdary of "family." 
The concept of amily usually covers the parent-chile relations of three direct gencrations and une generational sibling relations. As the zorizental, difect sibling ties have become more prerious with fewer dilkdren, sisterhood and maternal fannily tes save strengthene:

According to a 1996 survey by the Aariona. In Formation Office (NIO), whose sample size was 1.500 dramn zationwide, farnily is tie most impotant source to tely or for most contemporary Koreans. To the questio: of "who do you seek when yoli are in. rroujle," $41.9 \%$ answe:ed "faridy or relatives" while $31.6 \%$ answered "friends or senior confidants (umbar)." Where asked to wha: degree one consilts family when one is is. trouje, $56 . \%$ answered posie:vely ("very much so" $15.6 \%$ and "somsewhat" $11.2 \%$ ).

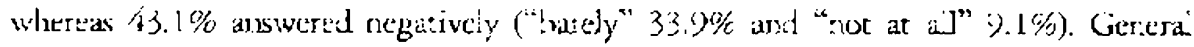

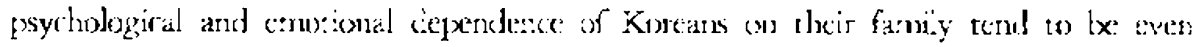
Ereater. Approximately 9-.2\% of the slivey participanrs answered that they har. a.fectior. towards thair tam!ly menthers: "very stromp" (70.3\%) or "scmewha:" (26.9\%), and $68.3 \%$ answered that they deperded on their Samily wher they fare difirnlties The so-calied "welfa:e fanction" ci the Asian family is ans griat: $90.8 \%$ of respondents answered that ":hey can give supporr io a family" member when he or she is in trouble." This data shows that the comrronly held thesis of high farrilial trust for Korears is cetcaisly valid.

\section{Generalized 'Irust}

In conerast to high (quas:-) Eami.y trust, gercralized tmist--used interchangeably with s.xial trist in this paper--is relarively low as has often been argued. Acrording to the Sejong Surey carried our :n $1995^{3}$, axou: $47 \%$ of Koreans think that nojody woild relp them it they suffered an injustice: people who would help them would be fanily merrbers, but ror strangers. More signuticant'y, approxumarely $81 \%$ of Ko:eans think

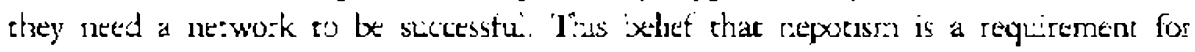
success selies the enyt: of an atheve: acr:-oticned sociciy based on educativial crecontadism in Korea. Distrust of the "rule of low" is so substintial that aloout G8\% of Korfans thir:k that they w:Il $x$ a fialuse if they atide hy the reies.

I ABLE I, Genezalized l'kUS' IN KuReA

\begin{tabular}{|c|c|c|c|c|}
\hline & \multirow{2}{*}{\multicolumn{2}{|c|}{ Stringly }} & \multicolumn{2}{|c|}{ Stromedy } \\
\hline & & & Agree & Apree \\
\hline 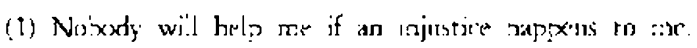 & 4. & 486 & 39.4 & ? i \\
\hline (2) One needs a netwitik to sucteeo in the socity. & 3.9 & 15.1 & 57.3 & $24 i$ \\
\hline (3) It o:1e ..ves by the cules he or she will a loser. & 2. & 29): & 56.3 & 119 \\
\hline
\end{tabular}

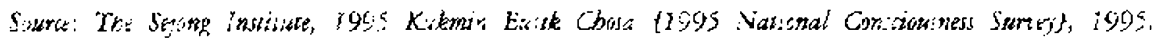

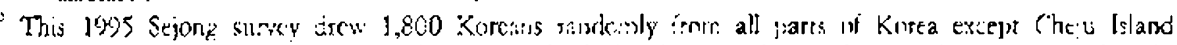

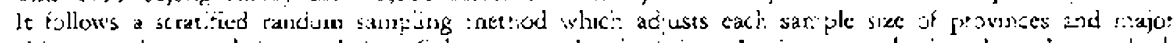

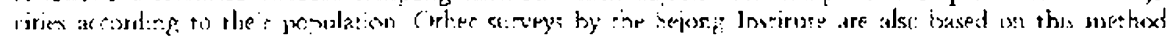


As for general interpersonal :rust, sinpessing!y this basic question was sot asksd continuous.y. According to a I 1888 survey by the Korcan Political Association, 67.1\% of Koreans agrexed that "one has te: taxe care of himself, otherwise one is likely to be expinited by other people" (Iee and Kim 1988; - Only half as many respondents disagreed. To the sinilar guestion of "co you think that mort people can tee trusted or that one cannor be too careñl atout tien?" ponsed by the Japanese Ministry of Educaton, the Japanese respondents who a.sswered that most people can be crusted has risen foom $26 \%$ in 1978 ro $31 \%$ ir. 1983 and $38 \%$ in 1593 . If $52 \%$ of japanese in 1993 and $67 \%$ of Korears in 1988 did no: trist other peopie, one can interpret

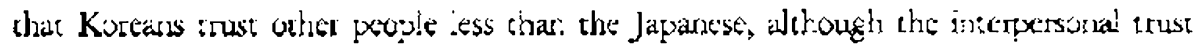
level is low in both countries.

If we take guestion (1) :0 vindestand the diferences by individual baikground variabes, ther age, ecucation, and income fartors applear to be sigrificant. In the four srale point (lower sroce means higher raxe:), yourger people in the:r $20 \mathrm{k}$ score ?.6, which $: s$ higher than 2.5 of penple aged berween 30 and 59 and 2.4 of people aged 60 anc over. Also, noore edicated people demonstrate a uigher evel of interpe:soral trust. Specifically, the average roust sco:e of peop.e with a primary or middle school educat:on is 2.4, while tha: of high school graduates is 2.5 . Those who received a inversity education and above soure 2.6. As tixe income level drops from upper, middle to lower, the average teust ponnts also decrease from 2.6 to 2.5 ard 2.4 .

\section{Institutimed and Political Trust}

The 1995 Sejong s:irvey indudes a set of questions related to political trist. As we can see in che following :able, $86 \%$ of Koreans think trat policicians do nox keep their election promises, and $30.4 \%$ of therr. aso believe that politics is dominated by a minority who do not care about the people.

Table 2. POLlTICAl Trust in Komes

\begin{tabular}{|c|c|c|c|c|c|}
\hline Polizical Trusi & $\begin{array}{l}\text { Strongly } \\
\text { Uppose }\end{array}$ & $\begin{array}{l}\text { Sonie. } \\
\text { Oppose }\end{array}$ & $\begin{array}{l}\text { Some. } \\
\text { Agree }\end{array}$ & $\begin{array}{c}\text { Strongly } \\
\text { Ag:exe }\end{array}$ & Me:ars' \\
\hline $\begin{array}{l}\therefore \text { Pclicicians ton: keep their electicn pro- } \\
\text { mises. }\end{array}$ & $65 \%$ & $7.4 \%$ & $44.2 \%$ & $41.8 \%$ & 321 \\
\hline 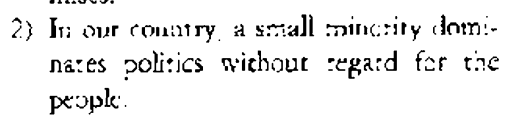 & $69 \%$ & 12 - & $\therefore 6.9 \%$ & $31.5 \%$ & 3.05 \\
\hline
\end{tabular}

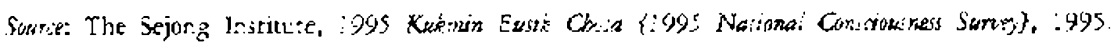

When aak:ng the statement of "(x)':kicians dor:e kexp thrir dection promises" as an incicator of political trus:, age appeass to be signicicar." facton. The menc1 score of trist (here lower score nurias less rus:) for peopie between 2.0 and 19 is 1.7 , while those of peopie ir. their 50s and 60 s + increases to 1.8 and 1.9, respectively. Younger 
and middli-aget. Koreans tend to distus: their politicians :nore than older Koreans. This is the opposite :endency of interpersorial distrast, which eends to be stronger with older Korcaris.

The level of irstituticnal trust is also low even rhough it tends to be letter than the sirong cissrust against pooiticians anc. politics. Look:ag at the three hranthes of the government-rthe parliamen:, the adm:nis:ation, and the court-ne san find that the parlianent is the least trusted ancrng thern, with $74 \%$ of Koreans distristing their parliament. 'This refects Kureans' disillusionment arith their rep:esentative denocracy. On tine othe: hand, approximately $58 \%$ of Kortars cistnist their auministration. If we consider that it:c Korcan government has been generally viewed as a compercon meritoctacy, the face that only four Kortanns out of ten trust their governencin cannut bx posinively interpectec. Korrens' toust toward their coun is réatively stronger; with slyghtiy roore than nalf of the peoulation. tristing the court.

TABLE 3, INSTITLTIONAL TRLST IN KOREA

\begin{tabular}{|c|c|c|c|c|c|}
\hline Inst:cutional Trust & $\begin{array}{l}\text { Absolute } \\
\text { Trukt (\%) }\end{array}$ & 'rust (\%) & Distrust (\%) & $\begin{array}{c}\text { Absolute } \\
\text { Distmist (\%) }\end{array}$ & Mean ${ }^{\circ}$ \\
\hline Patiament & 1.6 & $2 . \dot{3}$ & $6>2$ & 33.7 & 28 \\
\hline Administration & $2 \hat{3}$ & 39.9 & $5: .8$ & 5.9 & 2.6 \\
\hline Colrt & 34 & $4: 2$ & 43.3 & 6.2 & 2.) \\
\hline
\end{tabular}

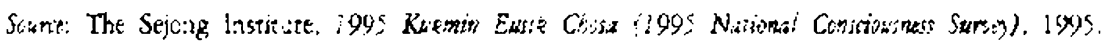

Age is also relatec to institurional trust as $\therefore$ is for political trast. lior example, the meare trist score of pecple between the age of 20 and 49 is 2.9 (here, lighe: score

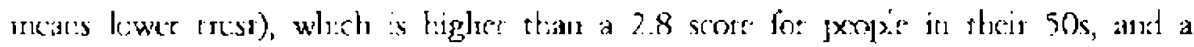
2.7 score for pecple in their (xis ard ever. The sarne pareern applies for Kotears' trust reward the administration. Mear retser scone ciecseases as afe increases, i.e. 2.7 amon.g $20-30$ year olds, 2.6 among 40 year olcs, and 2.5 arrong $50,-60$ year olds. As the same time, mo:c eciucatec Korears hold̀ less instititional trust. People who reccived a midde sthool education or less distnist thei: goverrment less $(2.5$ point $)$

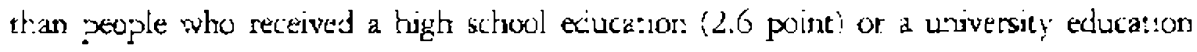
(2.7 point).

Therefore, ore can sumanaree that younger Koreans iond to hold higher inser

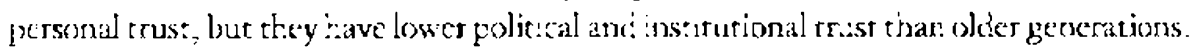
Also, more educared Koreans ten! to have higher interpersonal trust whie they samonscrate ronsiterably lower policica. and irstitutional trust.

\section{CIVIC ENGAGEMENI'}

1.)ata on Korcan esvic life is very limstece. In this part, a slort review of Karean civic liee is hased on she 1996 . No survey. 
Koreans' neighborhood at:achumer: also appeass :o be quice strcag with a sigrificant

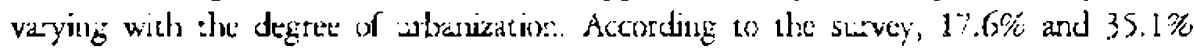

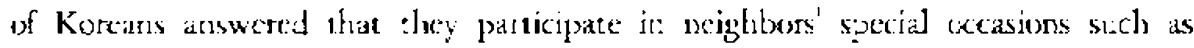
birthdays, marriages, funcra's, and ere "all the time" and "freejuently," respectively. Neightorhood interaction is grearer in countryside ( $66.4 \%$ for either "all the rime" or "f:equent.y") than in smaller cities (58\%) or larger cities (42.3\%). Neighborhond mutual help :s also greater in less urbarizeci areas: $83.8 \%$ of rural area residents expect their reighbors' help in case of burglary or are: "a great deal" (26.3\%) or "sumewhat" (5:.6\%), whereas orly $62.3 \%$ ef large city dwellers expect such helo, "a great deal" $(8.8 \%$ ) or "scmewhar" $33.6 \%$ )

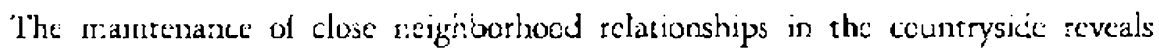
that strorg fanily tes are crassferting to the local commonity where face to fact

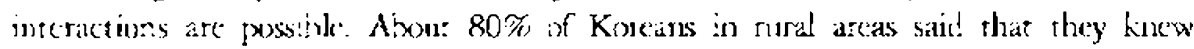
most :xople in treir community, whereas only $16 \%$ of lange ciry dwellers did. In the rase of urizan areas where one's neiginon: is discant and anonymons, workplace provides a communitarian role instead. Koreans expect and maintaia irformal interpersor:al ties wich co-workers. Altiough Korean comparies gua:antee 'ess job security ar.d provide less corporate weltare tian Jasanese comparies, "work lite" is an integral part of Kurean workers' :nterpersonal relaricnshps. 'Ihe rea! question would be how close family, neighbortood, or workflace ues are related es ahe e:vic life of Korcans.

Taliti 4. Korkans Participating an C:vir associationis:

\begin{tabular}{|c|c|}
\hline Tota: & 29.1 \\
\hline \multicolumn{2}{|l|}{ Gerder } \\
\hline $\mathrm{Men}$ & 34.1 \\
\hline Women & 21.3 \\
\hline \multicolumn{2}{|l|}{ Age } \\
\hline $20 \mathrm{~s}$ & 26.0 \\
\hline $30 \mathrm{k}$ & 28.5 \\
\hline $40 \leqslant$ & $3 \div 1$ \\
\hline Siks and over & 30.3 \\
\hline \multicolumn{2}{|l|}{ Exda: ation } \\
\hline Muldere showi and lass & 33.2 \\
\hline Figh school & $2^{-} \cdot 4$ \\
\hline College and nors & 36.4 \\
\hline \multicolumn{2}{|l|}{ Manthly lnconse level } \\
\hline Low (1.' milior wen and hiss) & $2 j .4$ \\
\hline Midcie (1.41 milior: 2.5 millicr wn) & $2 \% 4$ \\
\hline Lperer $(2.51$ mollion wost arci ores) & $3: 5$ \\
\hline \multicolumn{2}{|l|}{ Restidertial Arez } \\
\hline Large ciry & $2 \div .4$ \\
\hline Sma.-mediun: sized sty & $2: 8$ \\
\hline K(แ⿰扌) arcis & 33.6 \\
\hline
\end{tabular}

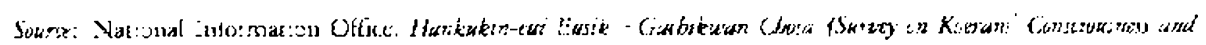
$\because x\left\{x_{t}\right\}, \quad 1306$ 
According to the VIO data, three cut of ten Kureass participate in sorre kind of association. Men adker than women, midjle-igex ratien than younger people, rural residents rather than city dwellers, more coluated and affluene tend :o crigage in civic life in Korea.

Three majcr associations to which Koreans belong are fraterrity groups (58.9\%), religious associations (33.)\%\%) and social service associations (17.4\%), followed ay hobisy groups $(9.5 \%)$ and same accuparional groups $(8.6 \%)$. (jvic ergagement in orher kir.ds of associations is meager. ars associations (3.6\%) political part associarions (2.1\%), envirunnenta. assuciations (2.5\%), anc ex, As for an associacion in which Kortars want o participare in the fitute, 22.3\% showed no interest, whly the rest idertified a cerain catcyory of civic associations. If we conseder the fact that only three out of ten Kuteans belcng to any civic association, but seven out of en Koreans want to participate in civic associaticns in trie futuze, potential grcwth of a civic Korea seems to be sigrificant. In particliar, Konear. inzerest in furure civic activities tand to je sujstantia! in social seruce and environmental protection. One analys:s states that approximately three cuarters of non-rei:gois Krisean NGOs related to civis activites

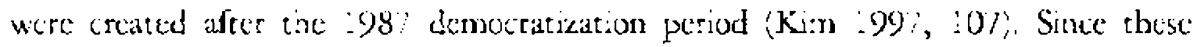

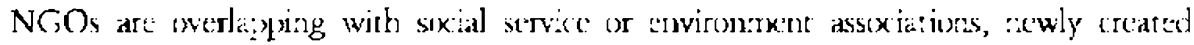
associations of public interests are likely in house Koreans who want to be more participatcry in sivic life.

Comparable dara sugges: that about $40 \%$ of Americans and arout quarter of Japanese (26\% in $1981,25.2 \%$ in $1986.27 .7 \%$ in $: 99$ !, and $25.3 \%$ in 1996 , according to the Statist:s Bureau of the Nanagerren: and Coruination Agency, Irogrchi 1998, 6) paricipate in civic activites. In lhe Japancst case, cive activities we:t defined as activities for neighborhood or larger areas and sorial welfare facilities, as well as volunicer actuvites l:chpirg chidtren, rhe agece, the disadvantaged, and disaster relef arrivites. Altzough this dasa cannot offer a goot comprason sirce sivic activirces are defines differently, se can say thar Kurean civic engagemert is not partic dar.y low compased to that of the Japanese, who are known to be more community oriented thin cthe: Asiars.

However, if we take a rote "termal" civic comnunity, Japan has more orgariza:ions and ramixers. Accurdine to Tsujulaka (2000), the number of registered nen. profit organizaticas (NPO) pe: 100,000 persons is 511 in the U.S., 273 in Japan, and 65 ir. Korra, w'ich is a 19:::0.2 ratio. One miy enslude that Korfar local and informal civec asscciarional life is guite acrive, athough its civis worle tends to be smaller anc limitec. On ti:e cher hand, grass:oors membership in lisger and national civic associations representing the newly emerging "civic movement" in Korea is relativoly limited.

\section{POIITICAI. PARTICIPATION}

Korea's de:uoxracy is barcly foureen years old since the natiors remocracizacion in 
198/, and is is important :0 turderstand Korean political participation in the consext of this retw derrocraxy. The Democratization of Korea cemonstrated the contentious nature of civil soxiety thromgly artive anti goversment movements against past autheritarian regimes, and the mass proteses that contributed to tive democratic transition in 1987. In corsolicatirg cemxracy, however, the mohilization of Korean civil sociery in protest against the au:horitarian government has heen replacec by its participation in national politics and pciticy-making processes. Patterns of political participarion by larger, cen:ralized civic associaticrs have been ar.creasingly focused on their "acvocacy tole" vis-ris the Korean goverrment. In this way, the Kurean civil society has begin to play a signicant role tor the navion's reform policies.

The political activation of Kurtan civic associations, hewever, has been led by uvic

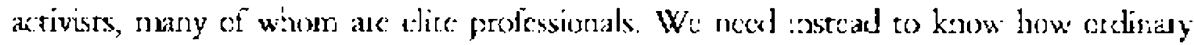
Korean citizens engage in politeral activities. Wril' they $h$ rather inacrive since formal demoratzation nas been achieved? Or on the contrary: will they te more acrive as they gair more freedon: and opportinity to paricipate in politirs. In what sollows, the trenc of voting rates and pat:erns of poitici participaion are exarniced on the basis of the Sejong survey datì ce 1995, 1996 and 1997.

'The analysis of the Seiong data suggests that peop.e who are active in cne kind of political particifation are lixely to be also active in another, I"ve different forms of political parcicipation ard anoriser ive fornas of protest are trawn fion che 1905 and

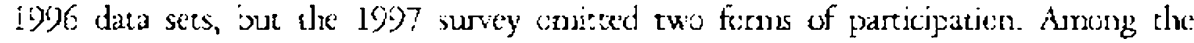

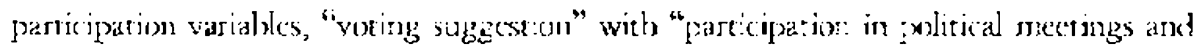
garherings" (1995, $: 956$ and :997), "discussion of :ub"ic affars with public offic:als and polit:cians" with "voting suggestion" (1996) anci the same variable with "participa: nn in political meer:ngs anc gatherngs" (:996 anc 1997), "cischission of public affairs with public officials anc pc.iticians" with "donation of money" (1995 ard :996), aad "participation in political meet:ngs and gathe:ings" with "donation of money" (1)96) are closey related to each other. As ser the protest varables, "participation: in legally sanctioned protests" with "colsemt to strikes or work stoppage" (1\%)6) anci the sanke variajle will: "filing of consticu:ional ciallenge" (1997), aned "consent to strikes ur work stopjage" w:th "sc:aurc of puilic bu:"dings" (1995 and 1996) are (loxely relatex to eush orher with more than 0.4 correlation cofffrienr within the $95 \%$ confidence level.

As seer: in the following table, the most common polic:cal pazicipation for Korcans in the past several years has been os "ralk about policics wich ceher people." Ir: 1995 and 1996 respectively, $43 \%$ and $48 \%$ o: Koreans ralked abolit politics with oriner peop.e "occasionally" and $11 \%$ and $9 \%$ calied "freçuerdy" On the other hand, Koreans engage in ethe: kinds of participatory astivities much less frequently. People who answisec "rot at a'" or "suggest to others :o vote for a spectic :erson ar a pary" have increased fom $48 \%$ in: 1995, to $54 \%$ in 1906 and $60 \%$ in I09? Tins disengagement phenomenon scers to be related to the rise of autmomy in voing derisuns. Ore would be retrianed from naking voting silyzestions when perple make treir choce more so'idly as in the presidensial election. But, about 15-16\% of Korcans 
cortimed to induenec the vouirg derisions of other jxople. People who engaged in activilics such as "participating in jolitical meetirgs or gratherings" and "distussing rommuniry or national affairs with public officials or poliricians" have becn 'ess than $10 \%$ in the past three surveys. Poitrical donation is the least engaged activity.

IABLE 5. Pattekns of POSITNE INPLT politlical Pafticipation

\begin{tabular}{|c|c|c|c|c|c|c|c|c|c|c|c|}
\hline \multirow{2}{*}{$\begin{array}{l}\text { For the past severol } \\
\text { years, how often have } \\
\text { you engaytu in cach of } \\
\text { the f(]) lnwing activities? }\end{array}$} & \multicolumn{3}{|c|}{$10 \times 5$} & \multicolumn{4}{|c|}{1996} & \multicolumn{4}{|c|}{$: 1927$} \\
\hline & (1) & $(2)$ & (3) (4) & (i) & (2) & (3) & (4) & (1) & (2) & (3) & (4) \\
\hline $\begin{array}{l}\text { Talk abou: poitics with } \\
\text { o:her pooble. }\end{array}$ & 12 & is & $43 \quad 11$ & $: 7$ & 31 & 48 & 2 & 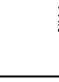 & & & \\
\hline 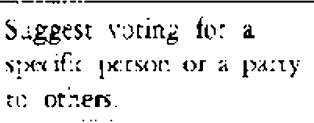 & 18 & $3 ?$ & & 54 & 32 & $1 \%$ & 3 & $(x)$ & $2 / 4$ & .3 & 3 \\
\hline $\begin{array}{l}\text { Fartic pare in polltrcal } \\
\text { meerings or gatherings. }\end{array}$ & 62 & 27 & 1) & $\because 1$ & 20 & 8 & 1 & 73 & 18 & 8 & ] \\
\hline 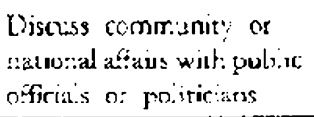 & 60 & 26 & $i$ & :s & 18 & 6 & i & - & & & \\
\hline $\begin{array}{l}\text { Domate to a political parcy } \\
\text { cr a poli.cias. }\end{array}$ & 84 & $: 3$ & 2 & 38 & 10 & 2 & 3 & - & . & &. \\
\hline
\end{tabular}

Net: 1: $190 ; \mathrm{N}-1.800 ; 1996 \mathrm{~N}-1,500: 1007 \mathrm{~N}-: .500$

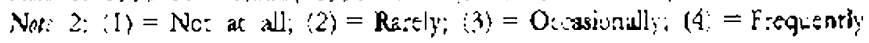

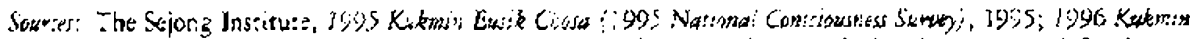

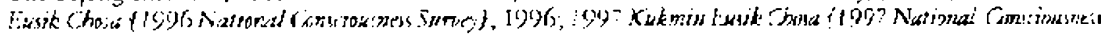
Serro, $19 \% 7$.

In contast to the lukewarm po.tical particpation in terms of "positive input," attituct's on political protest, or "riegative inpue," is mech nore active. More than $\$ 0 \%$ of Koncans suppor "peritioniag puble officials" ard more than $60 \%$ of thern suppor "particlating in legally samtioned presests" in surveys of the past thee years. Also, 61\% supjorat "filing constiturional challezpe to high cousts" in the 1993 survey. However, opposit:un to "esisting pevernment policies such as rot pay:ag certain raxes" exced support for it by approximarely 10\%. Opposition to "consenting to strikes or work stoprage" cr. "seizing publix bu:Idings" is secominant. Axout 82-85\% c: Koreans opposed the former idea in the past three year surveys, and more than $90 \%$ of them opposed the latter idea in the 1995 anc the 1996 sureys. The mears of protes: terd to be kep: whthe the bourdary ut law and corder.

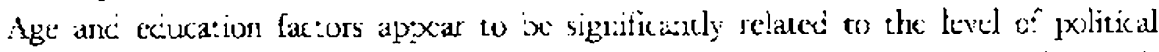
paricipation. In particular, as coc is more coldated or is younger, he or she terds to vica politacal protests as legitimate. Younger people tend to be less engaged in jx)litical tehavion. Fxirpt citizers aged 60 and over, as one is youzger, he or she tonds to participatc less in political meerings or is less likely to recommend rating for 
a specific politician or varty. But, the discetion of education factor on the positive inpur type of politica partic pation is not clear. In other werds, younger Koreans ectud to ix liberal in legitimizing various prorest behaviors b:at thry are less actue an eigaging in routine political behavior. Inwer voting rates among younger Kneans is a goxi example. A'so, the mose edicated one $\vdots \mathrm{s}$ ir. Korea, the more likely he or she is to accest the 'egitimacy of political protests.

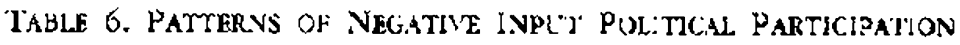

\begin{tabular}{|c|c|c|c|c|c|c|c|c|c|c|c|c|}
\hline & \multicolumn{4}{|c|}{995} & \multicolumn{4}{|c|}{1996} & \multicolumn{4}{|c|}{1997} \\
\hline & (1) & (2) & (3) & (1) & (1) & (2) & (3) & (4) & (1) & (2) & (3) & (1) \\
\hline Ptt:son pusilic offic.als. & 3 & 13 & 64 & 20 & & $: 2$ & 64 & 20 & 3 & 14 & 65 & 16 \\
\hline $\begin{array}{l}\text { Resist goveenment policies } \\
\text { (c,g no: pay ctr:ain :axts: }\end{array}$ & 8 & $5 \hat{2}$ & 33 & 6 & $1^{-}$ & 47 & 30 & 6 & $: 7$ & 43 & 33 & 7 \\
\hline $\begin{array}{l}\text { Participate :is legally } \\
\text { sancrousd givicsts. }\end{array}$ & 9 & 30 & 49 & 13 & 16 & 2.7 & $A B$ & 33 & 11 & 27 & 47 & 15 \\
\hline $\begin{array}{l}\text { Corsent to stukes e: } \\
\text { work stoplyagte. }\end{array}$ & 22 & 6 & $: 6$ & 2 & 30 & 52 & 16 & 2 & 22 & 53 & 22 & 3 \\
\hline $\begin{array}{l}\text { \{1925-1996 (pustior:) } \\
\text { Srize pistir buvidings. }\end{array}$ & 41 & $5 \mathrm{i}$ & - & & 46 & 46 & 7 & fi & - & - & - & . \\
\hline $\begin{array}{l}\{1997 \text { givest:on\} } \\
\text { File : ons:itu:iona chailenge } \\
\text { to the high courts. }\end{array}$ & - & - & - & - & - & - & - & - & 8 & 31 & 49 & $: 2$ \\
\hline
\end{tabular}

Nipe : $1595 \mathrm{~V}=1.840 ;: 996 \mathrm{~N}=1,500 ;: 90 ; \mathrm{N}=1.51 \%$

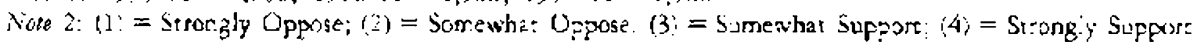

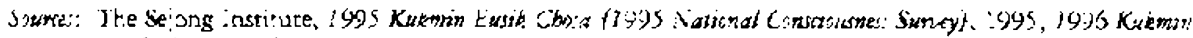

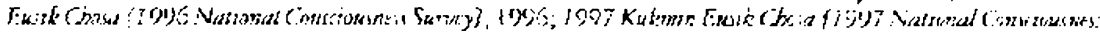
Starcyis. 109?.

Looking at the velationship be:ween partcipasion vaziables anci protest variables, correlation coefficients of ten variables in 1995 and 2996 , and those of seven variables i: $199 \%$, are al'. pesitively related except one within the $95 \%$ confidence level. Thus:

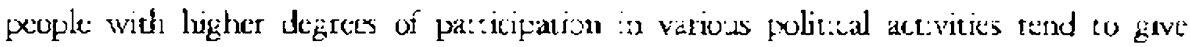
greater suppore so the various anciass of pliblic protese, and vice versa. Thus means that

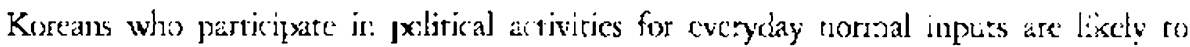
be rebellious when they see their protests as being legitinate. One carno: find a

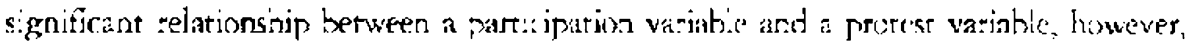
wher ore limits its significance to the level of more than a 0.4 cortclation cosfficient. On the other basci, both relatiorships anong the participation vatiables and anong the protest variables tend to be closer, especial'y among the former.

On the otier hand, Koreans who ate more particpatury in politics send to be less 
satisfied witl the deruevatic performance of their government. Interestingly, there is no sratistically meaningf:1l fiodings in the 1996 cata. Table 7 deronstrates trat a meanirgful difference in viewing, the demoratization of the Kim Young Sam era is found only in cerain ases. Fxcept for tize one iten ir. the 1997 surey, one car. fird fron tre 1995 data tivat people who are frecuently engaged ir. poitical activities, such as calking polttics, suggesting rotes, or going to political rreetings, tend to give a lower semocratizazion scure for the new demceracy. Although it is difficult to genera.ize duc to the limited number of metaningfid ioms, the liys daia diastrates tha: act:ve partcipants in cortain pulitical neput activitics tond to sce the new demoxracy as less derme: auc.

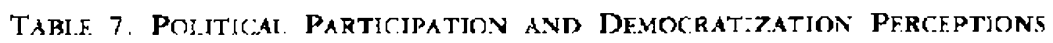

\begin{tabular}{|c|c|c|c|}
\hline \multirow{2}{*}{$\begin{array}{l}\text { Modes of Poliriral } \\
\text { Paziciparion }\end{array}$} & \multirow{2}{*}{$\begin{array}{c}\text { Scales of } \\
\text { Participation }\end{array}$} & \multicolumn{2}{|c|}{$\begin{array}{c}\text { Demociatization Mtarl Scort of } \\
\text { Yourg Sam Kim Era }\end{array}$} \\
\hline & & $1995(N-1, \bar{x}(0))$ & $1957(\mathrm{~N}-1,500)$ \\
\hline Ialktig kislitics & $\begin{array}{l}\text { Net at all } \\
\text { Ranely } \\
\text { Drcasionally } \\
\text { Frecuer:ly }\end{array}$ & $\begin{array}{l}6.5(2: 4) \\
6.54(62.1) \\
6.5(561) \\
5.57(: 98) \\
F=6.34 \\
3>1=0.0064\end{array}$ & $\begin{array}{l}- \\
- \\
-\end{array}$ \\
\hline S'uggesung Vutes & $\begin{array}{l}\text { Nc: at all } \\
\text { Rurely } \\
\text { Oc:asionally } \\
\text { Freguer.tly }\end{array}$ & $\begin{array}{l}0.0(55)) \\
6.16(694) \\
5.56(221) \\
5.29(48) \\
F=5.64 \\
P>F 0000 x\end{array}$ & $\begin{array}{c}5.98(0.35) \\
5.70(3(4) \\
6.19(194) \\
5.29(2.7) \\
F=4.87 \\
0>50.0025\end{array}$ \\
\hline 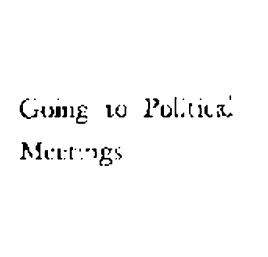 & 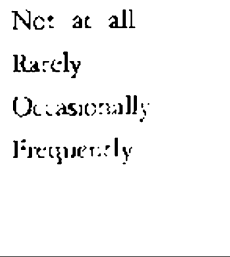 & $\begin{array}{c}6.14 \\
6.0: \\
5.7 \% \\
4.36 \\
F=10.11 \\
?>F 0.0000\end{array}$ & $\begin{array}{l}. \\
. \\
.\end{array}$ \\
\hline
\end{tabular}

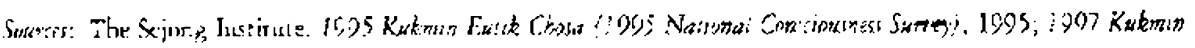

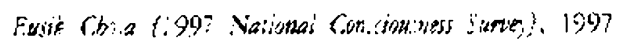

Attitudes toward pelitical protests ate mose strongly related to diffetent reactions :o

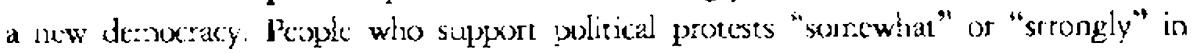

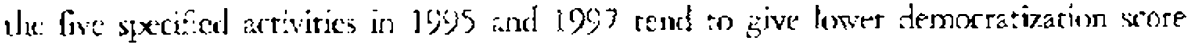
than rinose who onpese sucts prosest act:virics. Thus, Kureans who sec political protests as being efritimate tend to view a new democracy as less democratic than those who vic s therr. as illegitimare. 


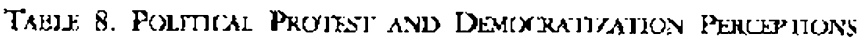

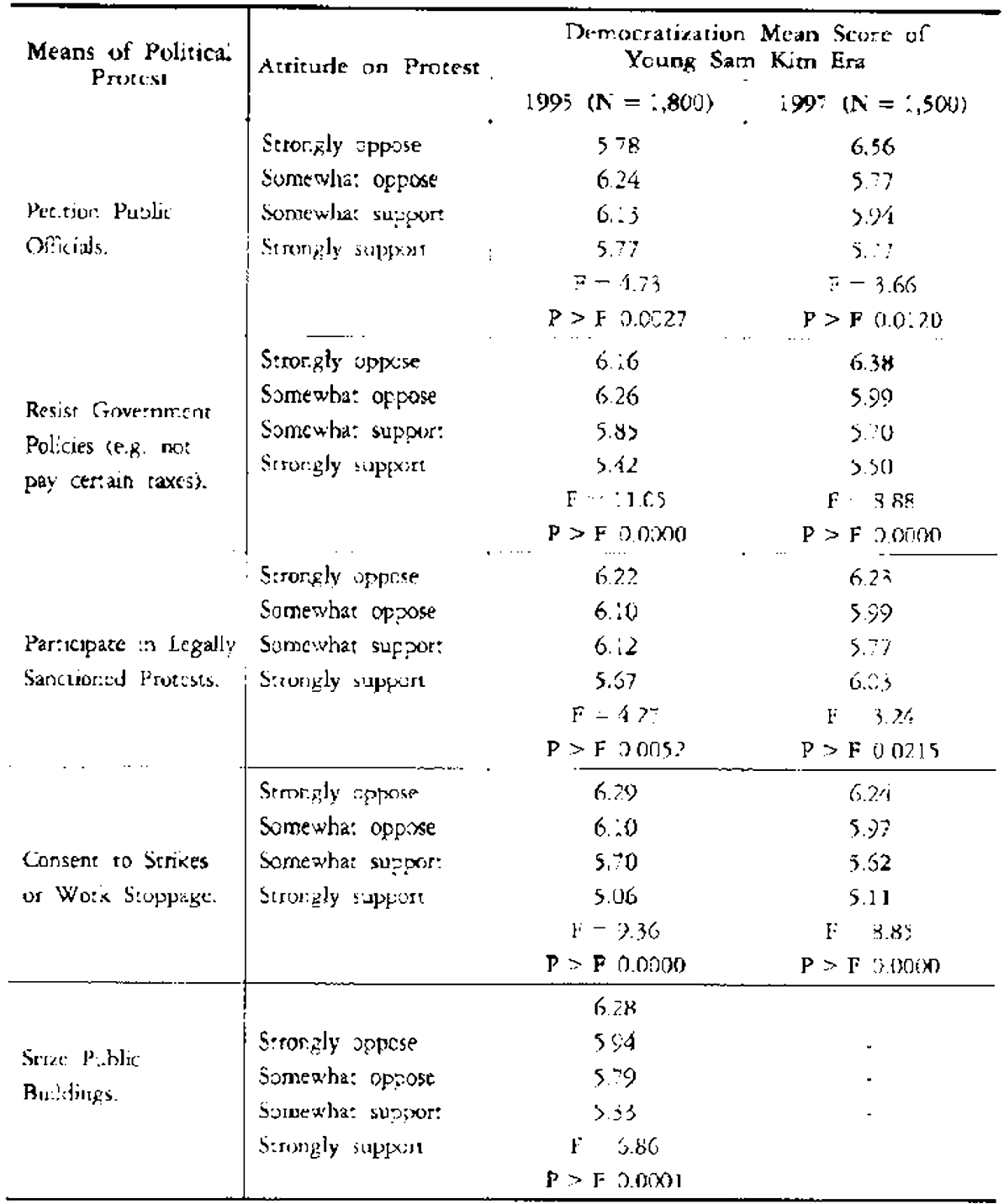

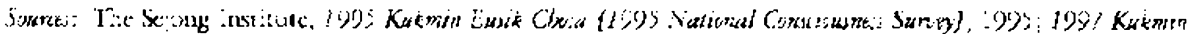

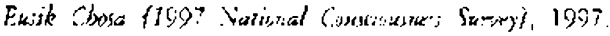

\section{CONCIISSION}

This paper reviented the status of trust in Korean sociery. We find that familial trust is high and neighborhond truse is relarive.y high. At the same time, civic activities in 
terms of assuciational merrbership is no: inative, even though the majority of associatiot:s to which Koreans are affilated iend to be limited to fraternity and religious arriverios. Conditions for sox:al concectedness, which can be generated through people's fare-to-face interacticns a varicus voluntary assoc:ations, seern to be presert. As a mateer of fact, Koreans like to build sœia netwo-ks and are busy at maintaining them. lrust and cooperatior. would be hig.a sithin these networks.

Vevertheless, generalized rust is low in Ko:ta. Although younger, berter edicated anc more atfluch Koreans re:d to trust orinel people and socia. no:ms such as meritocracy and the rule of aw, the overal level of gernetalized trast is low compared (o) Westera societies. Why fantigal or glass-familia rust based on particulatistic ties doxes nox transend to extsice soxieny begs a guestion. Korcan inectopersonal aetworks iecd to be limited to exclusive relaticrs such as scleonl anc ocruparional ties The prevalent pattern of Korean asscxiational life is based on common background and private interests rather than universal idencity and shared goals. This phencmemon seems to narrow the boundary of soc:al conrectedness and cocperation. Such an observation. however, coes not necessarily support fukuyama's conception of a zero-sum game berween familial trust and geceralize: inust. The racius of touse is certainly ex:andable as mort pecple participate in voluastary assocatons for fablic irterest and the public good. Ine growing civic organizations for woriad services and onler advorary assiniariom for e:

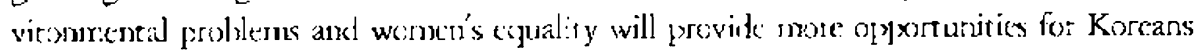
11) trust and cooperate at the higher levels of sixiety.

Institutional and axlitical trist is aso low in Korea. Inw generelized trist tends to ixe related to low institutional and wolitical crust. The :mpact of governance cn people's generaized roust is grea: urder underrocratic ale. When the police state supervises peoples activities, anc redia corcrage and cour ries are inticenced jy power, people cannot trist publ:s of:icials and heir instru:ions, nor can they trus: orher peeple easily. Severa' decade old exper:ences uf autho:1tarıan regimes he:ghecineci Korearis' cistrust of thein goverumem and eleir socicy. Altheugh experiencisg the on going drive for mational

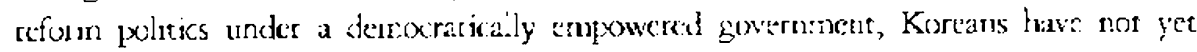
developer conficence in: their government's corperence and credibiliry. Distrust rowards politiciass and the pariament is worse due 0 com:3rion and acompetence. In con:rnst to the case co generalizes trust, poilicial distrust tends to be nigher among younger and educated Koreans.

Korears appsar to be less fartcipasory ir. political mee:ings or party activities. Younger pecple are even less participarory. However, as one is more educated and younger, they tead so more open :o poluteal pretests. These groups also believe that the democratically emonowed new governmen is of sufficiently denuxratic. They look ligher exicuations for demoxatization, which moars a hight frastration level for the status quis. The role of these penple for Kotea's demoxtary is imporeant since they have innere g;eneridized ans and hold the potential for civic and political artivity.

Thes pape: co'dld aot offer statiscica' analysts on the reationshp among :ause, civic engagement, and pciitical participarion. Irstead, it has snown a rough description of 
each elcment critical for the corsolication of demextaly in Korea. A mere enuaruert survey is needed to offer that kiad of analysis in the future.

\section{REFERENCES}

Berman, Shen. :99? "Givi. Sxiety ard Pulitical Institurionalization." Anzerzan Bebarioral Sciemtig 4i) (5) (March/Apil) 562-3<.

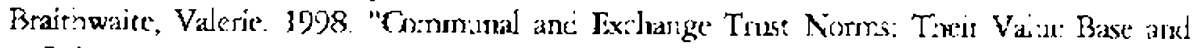
Relevance to Instrut:ona Tr.ist." In Trust and Gomtmance, ed. Valetie Braithaiaith and Margaret Levi. New Yo:k: Russeil Sage Fcundation.

Colcruar., James, 1988. "Social Capital in the Crearion of Human Capial." American Jaumat of Sixzhoge 94. 95120 .

1990. Foundutions of Sxiul Theary. Carubridge, MA: Belknaly.

Foley, Nichael W. and 3ob Fdwards. 1597. "Fscape From Policics: Soxial Theory anc the

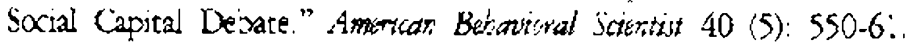

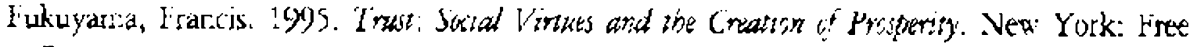
Press.

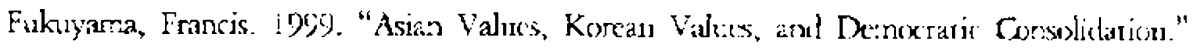

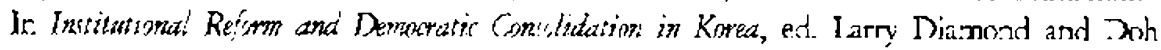
Chull Shin. Fonver Iastitution Press.

H tariin, Russell. :998. "Irust in Government." In 'Thut and Gsntrianfe, ec. Valerie Braithwadth. ated Margaret levi. New York: Kussell Sage loanciacio:1.

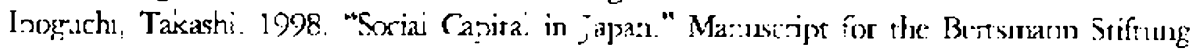
Projec: on the Declire of Social Capica.

Kim, Hyuk-Kae. 195j7. "Kotean NC:Os: Global Trend and Prospect." Gioba' Enomomic Revieuc 26. (2) (S.jmrrer). $93-115$.

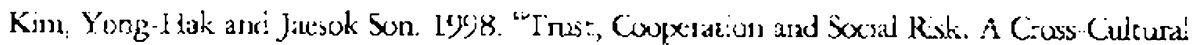
Compariscn." Korec joumal (Sproing): 13153.

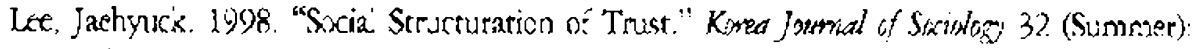
$3: 1-35$.

Lrvi, Ma:garet. : $\%) 8$. "A Salt of Inust" In Tiast and Goremance, ed. Valerie Braithwaith and Margaret Levi. Now York: Russell Sage leumciation.

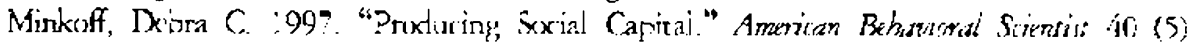
(Marcis April): $606-619$.

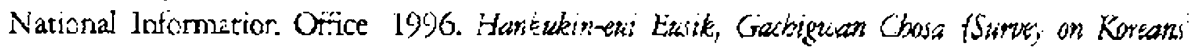
Cirascioisners and V'alues.

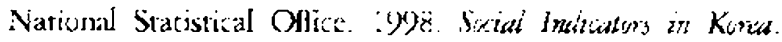

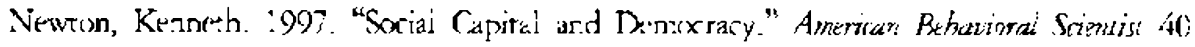
(5) (March/April): 575-86.

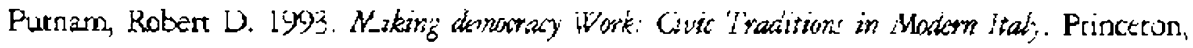
NJ: P:incelor: Utive:sity l'ress. $6,-78$.

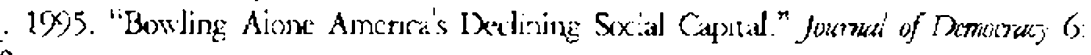

Sromol, Theda and Morrs P. Firrina. 1999. "Mazing Serse of the Cinc Engagement Debate."

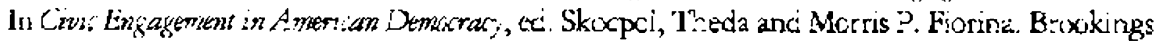


Institution Prexs.

Skoxpel, Theda. 1999. "Advocates without Member: The Recent Transformarion of American

Civic life." In Cinic Ëngagomm? in American Demacrac, ed. Sxocpol, Theda and Mcris

P. Fionna. Brookings Institution Press.

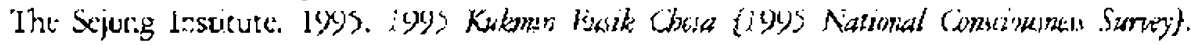

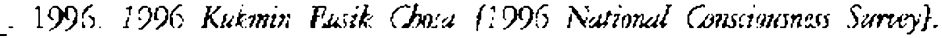
1997. 1997 Kumir Fasite Cho a fi997 Nationial (onsizousness Suney).

Tsujinaka Yutaka 2000. "Shir:-inShakaiSosiki no Mots. Niakan Ka-kei Shihon e ro lanplication: Nichi Bei Karn nu Hikaku Bunsek: LImplication of Civil society Organizations on Soxia]

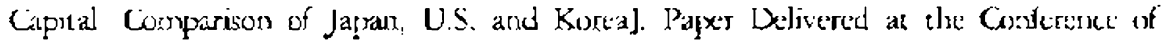
the Jatranese Assoxiation for Elex:ion Studics. Musiasni Kogyo Iniversity, Jatpan.

Tyler, Ton R. 1998. "Trust and Demixtar Crovernance." In Thui and Critmance, ed. Valerie Braithraisin and Margaret Let:. New: Yck: Russell Sage Foundaior.

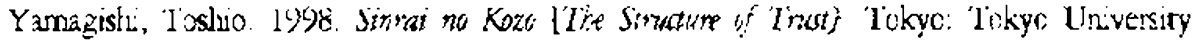
Press.

Yanaigish:, Tostio et al. 1998. "Inerestinty, Tause, and Comeniment Formations in the

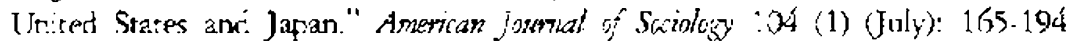

